DOI : 10.31357/fapsmph.2002.00602

Jomy loving parents 


\section{Declaration of the candidate}

The work described in this thesis was carried out by me under the supervision of

Dr. P.M. Jayaweera and a report on this has not been submitted to any University for another degree.

$07 \cdot 08 \cdot 2002$

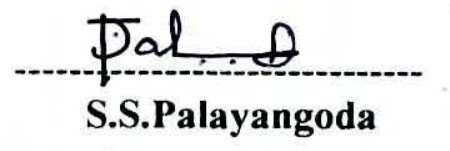




\section{Declaration of the supervisor}

I certify that the above statement made by the candidate is true and that this thesis is suitable for submission to the university for the purpose of evaluation.
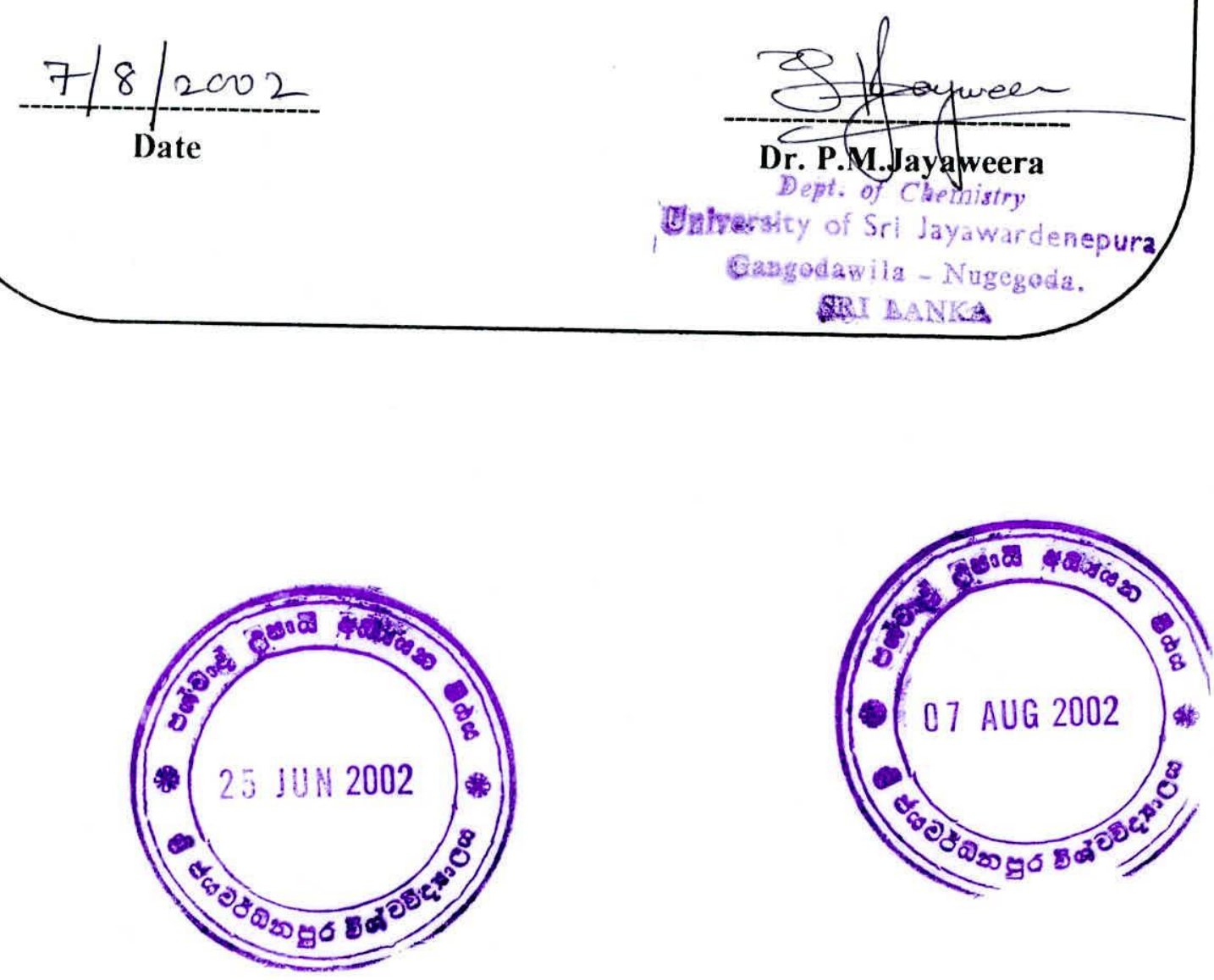
SPECTROSCOPIC AND ELECTROCHEMICAL STUDIES

OF IRON(II) AND COBALT(II) COMPLEXES;

POTENTIAL DYE MATERIALS FOR NANO-POROUS

PHOTOVOLTAIC DEVICES

\author{
By \\ SUJEEWA SENARATH PALAYANGODA \\ [ B.Sc.(Chemistry) sp., US.J, Sri Lanka]
}

Thesis submitted in partial fulfillment of the requirements for the Degree of Master of

Philosophy in Chemistry of the Faculty of Applied Science, University of Sri

Jayewardenepura, Nugegoda, Sri Lanka. 


\section{TABLE OF CONTENTS}

I.IST OF CONTIENTS

LIST OF TABLES vi vi

LIST OF FIGURES vii

ACKNOWLEDGEMENTS $\quad \mathrm{x}$

ABSTRACT

\section{INTRODUCTION}

\section{CHAPTER - 1}

1. Theoretical Background 1

1.1 Solar cells 1

1.2 Energy band gap of solids 3

1.3 Fermi level 5

$\begin{array}{lll}1.4 & \text { Charge carriers } & 7\end{array}$

$\begin{array}{ll}\text { 1.4.1 Photo-excitation } & 7\end{array}$

$\begin{array}{ll}\text { 1.4.2 Thermal excitation } & 7\end{array}$

$\begin{array}{lll}1.4 .3 & \text { Doping } & 7\end{array}$

1.5 Conductivity of a semiconductor $\quad 8$

1.5.1 Electronic conductivity $\quad 8$

$\begin{array}{ll}\text { 1.5.2 Ionic conductivity } & 8\end{array}$

1.6 Dye sensitization 9

1.6.1 Kinetics of the semiconductor electrode/electrolyte interface 11 
1.7 Efficiency of a Photo Electrochemical Cell

1.7.1 Drawbacks of the efficiency of the Photo Electrochemical Cell

1.8 Properties of electronically excited states of transition metal complexes

$\begin{array}{ll}\text { 1.8.1 Criteria for classification of the excited state } & 17\end{array}$

$\begin{array}{lll}\text { 1.8.1.1 Metal centered (MC) excited states } & 17\end{array}$

1.8.1.2 Metal-to-Ligand Charge Transfer (MLCT) states 18

$\begin{array}{lll}\text { 1.8.1.3 Ligand Centered (LC) excited states } & 18\end{array}$

1.8.2 Transition metal complexes as dye material for solar cells $\quad 19$ (Photovoltaic cells)

1.9 Fate of a dye molecule in a Photo Electrochemical Cell 21

1.10 Acid-base switching of alizarin and quinalizarin sensitized nano-porous 22 Photovoltaic devices

1.11 Cyclic Voltammetry 23

$\begin{array}{ll}\text { 1.11.1 Data interpretation } & 23\end{array}$

$\begin{array}{ll}1.12 \text { Computational Chemistry } & 26\end{array}$

1.12.1 HyperChem software package 26

$\begin{array}{ll}\text { 1.12.2 Building and displaying molecules } & 27\end{array}$

1.12.3 Optimizing the structure of molecules 27

$\begin{array}{lll}\text { 1.12.4 Molecular Mechanics (MM+) } & 27\end{array}$

1.12.5 Semi-empirical methods of quantum chemistry 28

$\begin{array}{ll}\text { 1.12.5.1 General background } & 28\end{array}$

1.12.5.2 Molecular geometry 28

1.12.5.3 Calculating electronic potential energy $\quad 29$

1.12.5.4 Features of semi-empirical method 29 
1.12.5.5 Range of semi-empirical methods

1.12.5.6 ZINDO/1 (Zerner's Intermediate Neglect of Differential Overlap) 30 method

1.12.5.7 Selecting options for ZINDO/1 method 30

1.12.5.8 Single point calculation 32

$\begin{array}{ll}\text { 1.12.5.9 Contour plots } & 32\end{array}$

1.12.5.10 Total electron density calculations (charge density) 32

\section{CHAPTER -2}

\section{Experimental}

2.1 Chemicals and Solvents 33

2.2 Preparation methods 33

2.2.1 Preparation of conducting glass plates (CTO) for applying $\mathrm{TiO}_{2}$ layer 33

2.2.2 Deposition of $\mathrm{TiO}_{2}$ on conducting glass plates 33

2.2.3 Preparation of $\mathrm{Fe}(\mathrm{II})\left(\mathrm{C}_{2} \mathrm{O}_{4}\right)_{2}$ bromopyrogallol red complex 34

2.2.4 Preparation of $\left[\mathrm{Co}(1,10-\text { Phen })_{2}\right] \mathrm{Cl}_{2}$ complex 34

2.2.5 Preparation of $\mathrm{Co}(1,10-\text { Phen })_{2}$ bromopyrogallol red and 34 $\mathrm{Co}(1,10-\mathrm{Phen})_{2}$ catechol violet complexes

2.2.6 Preparation of $\mathrm{I}^{-} / \mathrm{I}_{3}^{-}$electrolyte 35

2.2.7 Coating procedure of dye on semiconductor films 35

2.2.8 Preparation of acidic and basic ethanolic solutions 35

2.2.9 Measuring the photocurrent and photovoltage values of acidic medium 35 and basic medium dye coated photovoltaic cells 
$\begin{array}{lll}2.3 & \text { Instruments and techniques } & 36\end{array}$

2.3.1 Absorption and Reflectance spectra 36

$\begin{array}{lll}\text { 2.3.2 Photocurrent action spectra } & 36\end{array}$

$\begin{array}{lll}2.3 .3 & \text { Emission spectra } & 38\end{array}$

$\begin{array}{ll}\text { 2.3.4 Cyclic voltammograms } & 38\end{array}$

$\begin{array}{lll}2.3 .5 & \text { Solar simulator } & 40\end{array}$

2.3.6 HyperChem quantum mechanical calculations $\quad 40$

\section{Results and Discussion}

\section{CHAPTER -3}

3.1 Preparation of a dye sensitized photovoltaic cell 41

3.2 Preparation of a metal complexes 46

3.3 Comparison of spectroscopic properties of $\mathrm{Fe}(\mathrm{II})\left(\mathrm{C}_{2} \mathrm{O}_{4}\right)_{2}$ bromopyrogallol red $\quad 46$ complex with bromopyrogallol red free ligand

3.4 Spectroscopic and photovoltaic properties of $\mathrm{Co}(\mathrm{II})(1,10 \text {-phen })_{2}$ bromopyrogallol red and $\mathrm{Co}(\mathrm{II})(1,10 \text {-phen })_{2}$ catechol violet complexes

3.5 Emission and absorption properties of $\mathrm{Co}(\mathrm{II})(1,10-\text { phen })_{2}$ catechol violet and 65 catechol violet ligand in methanolic solution

3.6 Acid-base switching of alizarin and quinalizarin sensitized nano-porous 68 photovoltaic devices 
References

Conclusion

76

List of publications

77 


\section{LIST OF TABLES}

Page

Table 2.1 Average photocurrent, voltage and cell efficiency values for two dye $\quad 52$ materials [iron(II) $\left(\mathrm{C}_{2} \mathrm{O}_{4}\right)_{2}$ bromopyrogallol red and bromopyrogallol red free ligand

Table 2.2 Heat of formation values of cobalt(II) (1,10-phen) ${ }_{2}$ bromopyrogallol 56 red and cobalt(II) (1,10-phen $)_{2}$ catechol violet

Table 2.3 Average photocurrent, voltage and cell efficiency values for two dye 62 materials [cobalt(II) (1,10-phen $)_{2}$ bromopyrogallol red and [cobalt(II) (1,10-phen) ${ }_{2}$ catechol violet] 


\section{LIST OF FIGURES}

Page

Figure 1.1 Classification of solids and semiconductors

Figure 1.2 Charge distribution of semiconductor after ionization 6

$\begin{array}{ll}\text { Figure 1.3 Mechanism of dye sensitization } & 10\end{array}$

$\begin{array}{ll}\text { Figure 1.4 Ruthenium polypyridyl type molecule } & 12\end{array}$

Figure 1.5 The charge separation at the interface of particulate film and the 13 electrolyte

Figure 1.6 The photocurrent conversion efficiency curve

Figure 1.7 Mechanisms within the cell 20

$\begin{array}{lll}\text { Figure 2.1 Schematic layout of action spectra set up } & 37\end{array}$

Figure 2.2 Schematic layout of cyclicovoltammetry set-up 39

Figure 3.1 The mechanism of surface complexation of dye with $\mathrm{TiO}_{2}$

Figure 3.2 Triphenylmethane type molecules 45

Figure 3.3 iron(II) $\left(\mathrm{C}_{2} \mathrm{O}_{4}\right)_{2}$ bromopyrogallol red complex 47

Figure 3.4 Absorption spectra of iron(II) $\left(\mathrm{C}_{2} \mathrm{O}_{4}\right)_{2}$ bromopyrogallol 48 red and bromopyrogallol red in methanol

Figure 3.5 Cyclic voltammograms of (a) iron( $\mathrm{II})\left(\mathrm{C}_{2} \mathrm{O}_{4}\right)_{2}$ bromopyrogallol $\quad 50$ red and bromopyrogallol red in aqueous solution containing $1 \times 10^{-3}$ $\mathrm{MKNO}_{3}$ as the supporting electrolyte.

Figure 3.6 Photocurrent action spectra for nanocrystalline $\mathrm{TiO}_{2}$ films coated with iron $(\mathrm{II})\left(\mathrm{C}_{2} \mathrm{O}_{4}\right)_{2}$ bromopyrogallol red and bromopyrogallol red 
Figure 3.7 Photocurrent - voltage curves for iron $(\mathrm{II})\left(\mathrm{C}_{2} \mathrm{O}_{4}\right)_{2}$

bromopyrogallol red complex and bromopyrogallol red ligand

Figure 3.8 The time development of the photocurrent when cells were

illuminated with $750 \mathrm{~W} / \mathrm{m}^{2}$ solar simulator

Figure 3.9 Most probable structures of cobalt(II)(1,10-phen) $)_{2}$ bromopyrogallol red and cobalt(II)(1,10-phen $)_{2}$ catechol violet molecules.

Figure 3.10 Absorption spectra of cobalt(II)(1,10-phen) ${ }_{2}$ bromopyrogallol red and cobalt(II)(1,10-phen $)_{2}$ catechol violet in ethanol.

Figure 3.11 Reflectance spectra (a) cobalt(II)(1,10-phen) 2 bromopyrogalol red and (b) cobalt(II)(1,10-phen $)_{2}$ catechol violet complexes on $\mathrm{TiO}_{2}$ surface

Figure 3.12 Action spectra cobalt(II)(1,10-phen $)_{2}$ bromopyrogallol red and cobalt(II)(1,10-phen $)_{2}$ catechol violet complexes on $\mathrm{TiO}_{2}$ surface.

Figure 3.13 Photocurrent-voltage curves for cobalt(II)(1,10-phen $)_{2}$ bromopyrogallol red and cobalt(II)(1,10-phen $)_{2}$ catechol violet.

Figure 3.14 Emission spectra of cobalt(II)(1,10-phen $)_{2}$ catechol violet and catechol violet free ligand.

Figure 3.15 Energy level diagram of cobalt(II)(1,10-phen $)_{2}$ catechol violet complex.

Figure 3.16 Molecular structures of alizarin (1,2-dihydroxyanthroquinone) and 68 quinalizarin (1,2,5,8-tetrahydroxyanthroquinone) 
Figure 3.17 Acid-base effect on observed photocurrent and photovoltage responses of alizarin and quinalizarin coated photocell

Figure 3. 18 Contour plots of HOMO, LUMO of protonated and deprotonated 71 forms of alizarin and quinalizarin 


\section{ACKNOWLEDGEMENTS}

I would like to express my sincerest thanks to my supervisor, Dr. P.P.M. Jayaweera, dept. of Chemistry, University of Sri Jayewardenepura for his expert supervision, helpful advice and constant encouragement during the course of this research work.

My thanks are due to Prof. K. Tennakone and Dr. R. Senadeera, Institute of Fundamental Studies, Kandy for their support. I would also like to thank technical staff at the Department of Chemistry, University of Sri Jayewardenepura and Institute of Fundamental Studies, Kandy, Sri Lanka.

Special thanks go to Prof. A.P. De Silva, School of Chemistry, Queens University of Belfast and Dr. Daya Barlo, Department of Physics, University of Colombo for their kind help to get Elemental Analysis data and Mass Spectral data respectively.

I would also like to thank colleagues in the Physical Chemistry research laboratory, Department of Chemistry, University of Sri Jayewardenepura, Mr. R.G.C.R. Gamage, Miss. P.I. Godakumbura and Mr. C.N. Weeraman, and Mr. P.V.V. Jayaweera, Photochemistry laboratory, I.F.S. for their support and friendship over the last two years.

Finally, the University of Sri Jayewardenepura and National Science Foundation, Sri Lanka are greatly acknowledged for all the support and financial assistance (Grant No. RG/98/C/05). 


\begin{abstract}
Metallochromic triphenylmethane type dyes (bromopyrogallol red and catechol violet) have attracted attention of many scientists due to their potential ability to chelate with a number of transition metal centers. The dye materials belonging to this class is capable of producing high photocurrents and photovoltages when used as sensitizers in nano-porous $\mathrm{TiO}_{2}$ photovoltaic cells. However, slow photo-degradation of dye molecules and low photocurrent conversion efficiencies have been the major problem.

Complexation of a triphenylmethane ligand with a transition metal center shows enhanced photovoltaic properties when compared with the photovoltaic cells coated by free triphenylmethane ligand only. Electrochemical and absorption spectroscopic data suggest that the nature of the lowest electronic transition of such a complex as a $\pi^{*}$ (ligand) $\leftarrow \mathrm{d} \pi$ (metal), metal to ligand charge transfer transition. Photovoltaic cells coated with these transition metal complexes show higher stability for photo-degradation and incident photocurrent conversion efficiencies with a UV radiation blocking filter.

When catechol violet is complexed with $\mathrm{Co}^{2+}(1,10-\text { phen })_{2}$ moiety, it shows emission as well. Experimental and theoretical data suggest that the emission of this complex occurs from an upper ligand centered state and not from a low lying MLCT state.
\end{abstract}

1,2-dihydroxyanthraquinone or 1,2,5,8-tetrahydroxyanthraquinone can be used as sensitizing dye material in nano-porous solar cells, not only they produce fairly high photocurrent and photovoltage, when exposed to light, but also those properties show high sensitivity to the protonation and deprotonation of the 2 hydroxy group of the ligand when the pH value of the solvent is changed. Semi-empirical computational studies have shown that fine tuning of HOMO-LUMO orbitals are responsible for the sensitivity. 